\title{
A PROTOTYPE SWING MECHANICAL ARM WEEDER FOR WEED CONTROL OF ORCHARD TREES
}

\author{
Sehsah, E. M. E.*
}

\begin{abstract}
A weeder with controlled swing mechanical arm was developed to control and remove the weeds intra-rows orchards tree. The swing mechanical arm constructed from steel, ground wheel carried the arm. The DC Electric motor with $12 \mathrm{~V}$ was used as the source of power to operate the rotary blades Weeder. Three rotational speed 1600 rpm, $2200 \mathrm{rpm}$ and $2600 \mathrm{rpm}$ was adjusted and controlled by the short resistor circuit. The prototype electric Weeder was evaluated under three forward speed 3.2 $\mathrm{kmh}^{-1}, 4.1 \mathrm{kmh}^{-1}$ and $5.7 \mathrm{kmh}^{-1}$ at three rotational speed $1600 \mathrm{rpm}, 2200$ rpm and $2600 \mathrm{rpm}$ for weeder and two different blades. The result indicated that it could be able to use the electric power produced from the tractor can be used to operate of the electric weeder. The electric Weeder with controlled swing mechanical arm may be applied to control of the weeds in citrus orchards tree field. The rotational speed $2600 \mathrm{rpm}$ and forward speed $3.2 \mathrm{~km}$. $h^{-1}$ gave the maximum weeding efficiency under orange orchards tree field conditions. The blades weeder was more effective in controlling weeds than the Tines. The developed electric weeder may be ideal for weeding under orchard trees. The type of blades was non-effect on fuel consumption at constant forward speed.
\end{abstract}

KEYWORDS: Electric Weeder, mechanical weed control, orchard tree.

\section{INTRODUCTION}

$\mathrm{n}$ Egypt Washington navel orange (Citrus sinensis L. Osbeck) is one
of the most important species in the genus citrus and ranked first
among the species of citrus. It occupies about $35 \%$ of the total cultivated area of citrus, since its acreage reached about 79,426 ha with total production of 1,663,284 tons per year according to the last census, issued by Ministry of Agriculture, Egypt (2015). Egypt is one of the world's leading orange producers and exporters.

*Associate Prof. in Agric. Eng. Dept., Fac, of Agriculture, Kafrelsheikh Univ.33516, Egypt sehsah_2000@yahoo.de 
The orchard row middles typically require mowing several times per year to provide access through the planting for workers and equipment, to reduce vole habitat, and to reduce moisture in tree canopies. The challenge now lies in producing a machine that can mechanically remove the weeds between standing plants in the row, whilst causing minimal damage to the crop. The aim of weed control is to kill weeds or suppress them long enough for the crop to gain a competitive advantage. The effectiveness of weeding is inversely related to the weed growth stage at the time of treatment. Weed management in organic or low-input growing systems entails integrating preventive and curative methods (Barberi, 2002). To avoid crop damage, intra-row weed control is best delayed until the crop plants are sufficiently developed, but at this time the weeds are usually too big to be controlled effectively. Intra-row weed control often needs to be applied one or two weeks after crop emergence. Thus cultural practices and weed control prior to crop emergence (pre-emergence weed control) before crop emergence are critical in terms of maintaining weeds at a low density level in the early crop stages (Ascard and Fogelberg, 2008). Cultivators with rigid blades that cut off the weeds one to two $\mathrm{cm}$ below the soil surface are the most commonly used machines for interand intra-row weed control. Cultivators can be equipped with finger weeders or elastic tines for both inter and intra-row weed control (Cloutier et al., 2007; van der Weide et al., 2008). Elastic tines can act as both torsion weeders and vibrating tines, which differ depending on how the tips of the tines have been set (Cloutier et al., 2007; Pérez-Ruiz et al.,2015). A finger weeder is made up of a pair of disks that have peripheral fingers and can be inclined in relation to the soil surface. The disks rotate when they make contact with the soil. The fingers can be made of rubber-coated iron (hard-finger) or of plastic (soft-finger) (Cloutier et al., 2007). The finger weeders uproot weeds and lift them out of the crop row. The working speed can range from 4 to $12 \mathrm{~km} \mathrm{~h}^{-1}$. Torsion weeders consist of a pair of spring tines per row, pointing into the crop from either side of the row but under the crop leaves. Tines with different diameter (ranging from 4 to $8 \mathrm{~mm}$ ) can be interchanged, according to the crop growth stage and sensitivity to mechanical damage. Generally torsion and finger weeders are more selective than spring-tine 
harrows, especially in broad-leaved crops (Bleeker et al., 2002; Ascard and Fogelberg, 2008, Sehsah ,2018). Bleeker et al. (2002) observed a tendency for better weed control but also a greater crop plant reduction with the torsion weeder compared to the finger weeder. Fontanelli et al. (2015b) combined the use of the same intra-row cultivator used by Raffaelli et al. (2010) and the rolling harrow for post-emergence weed control in spinach planted in $20 \mathrm{~cm}$ wide spaces between rows on raised beds. Melander and Rasmussen (2001) found that the brush weeder was more effective in controlling weeds than the cultivator, but only slightly better, and the cultivator was cheaper both in terms of investment and use (Melander, 1998). Laser weeding prototypes have been developed for laboratory applications or for the greenhouse (Mathiassen et al., 2006; Marx et al., 2012b; Ge et al., 2013). Laser weeding robots can improve labor productively, solve the shortage of the labor force, improve the environment of agricultural production, improve work quality, reduce energy waste, improve resource utilization, and help farmers to change their traditional working methods and conditions (Ge et al., 2013). The advances in technology have created wide opportunities for weed management, and precision agriculture may become a key element of modern weed control (Bajwa et al., 2015, Griepentrog et al. 2007).

\section{OBJECTIVES}

The objective of this research was therefore to develop a swing mechanical arm with an electric Weeder for identifying orchards trees trunk locations, allowing a soil engaging tool to mechanically remove weeds in the row, whilst circumventing the orchards trees. Non-Chemical Weed Management in citrus Orchards swing arm may be used to mow weeds under trees and even up close to the tree trunks.

\section{MATERIAL AND METHODS}

A swing mechanical arm with an electric Weeder was manufactured and tested in laboratory of Agric. Eng. Dept., and evaluated in Washington navel orange (Citrus sinensis L. Osbeck) field, farm research, faculty of agriculture, Kafrelsheikh University, Egypt. A prototype electric weeder consisted of two main parts. The first part is swing mechanical control arm that made from steel with $1800 \mathrm{~mm}$ length. Two helical springs with 
$300 \mathrm{~mm}$ length constructed in two sides of the mechanical arm. The arm was hanged jointed in the end of the main frame. The swing mechanical arm carried the electric weeder and designed as hanged arm tracked under the orchard trees. The horizontal marker wheel with $90 \mathrm{~mm}$ diameter constructed at $1500 \mathrm{~mm}$ from the hanged joint to the rolling point of the horizontal rolling wheel. The horizontal rolling wheel employed to reject the blades weeder near the trees. The ground depth wheel constructed at distance $1500 \mathrm{~mm}$ from the fixed point of the arm to adjust the height of Weeder blades as shown in figure 1 . The second part consisted of an electric weeder included the electric motor with $12 \mathrm{DC}$ volte and 3 Ampere rotated at maximum rotational speed $2665 \mathrm{rpm}$. The short resistor circuit constructed to control of the rotational speed. The three rigid tines fixed on the Teflon disk with diameter $80 \mathrm{~mm}$ and $20 \mathrm{~mm}$ thickness. The disk is fixed on the electric motor shaft with screw in horizontal position as shown in figure 2 . The rigid tines length $230 \mathrm{~mm}$ arranged at angle $1^{r} \cdot{ }^{\circ}$ degree between each other. Also two steel blades with $120 \mathrm{~mm}$ length were set in $180^{\circ}$ degree on the Teflon disk drive of electric motor. The tractor model Foton 254 with engine power $18.5 \mathrm{~kW}$ used to operate a weeder under field conditions. The Digital Tachometer Laser HP-2234C was used to measure the rotational speed of development weeder. The developed mechanical swing arm with electric weeder was mounted between the front and rear wheel tractor in three-hatch point frame. To quantify the extent of weed infestation, the number and species of weeds were counted in $0.5 \mathrm{~m}^{2}$ areas for each plot. A wood frame with measurements of $1000 \mathrm{~mm}$ by $500 \mathrm{~mm}$ was used as a guide and was placed centered electric weeder. The dry battery 12 Volts was connected with the tractor generator. The tractor generator used to recharge the battery during the operation of a development Weeder under field conditions. The hanged swing mechanical arm on two orchards trees trunk on the row centerline. The graduate cylindrical was applied to measure the fuel consumption for each treatment conditions.

\section{Test procedure and laboratory test}

The electric power from the tractors' dry battery was evaluated to operate the weeder DC motor. The battery remaining rated and capacity was measured by using the Tektronix Oscilloscope Model TPS 2024. State of 
Charge (SOC) is defined as the remaining capacity of a battery and it is affected by its operating conditions such as load current and temperature. SOC is a critical condition parameter for battery management. Accurate gauging of SOC is very challenging, but the key to the healthy and safe operation of batteries. The SOC determined by the following formula: SOC $=$ (Remaining capacity/Rated capacity) (Strunz K, and H. Louie, 2009 and Young K. et.al, 2013). The testes for operation the electric weeder depending up on the dray battery that charged by the tractor generator was 2 minutes for every trail. The main treatment was measuring the battery remaining rated and capacity of the battery by using the Tektronix Oscilloscope Model TPS 2024 at three rotational speed 1600, 2200 and $2600 \mathrm{rpm}$ of electric weeder.

\section{Controlled of distance between swing mechanical arm and trunk trees}

The distance between the blade in weeder and trunk trees may be able to calculate by know the deflection of the spring that is adjusted to control of the distance between the mechanical arm and the trunk trees. The analysis of geometrical diagram distance for spring deflection and tree trunk distance was indicated in figure $3 \mathrm{~b}$. The, moving of weeder in forward direction affected of two helical spring, the helical spring (AB) will have compressed and helical spring BC will be extended. The deflection $(\delta)$ in helical spring (BC) could be analyzed from the diagram in figure $3 \mathrm{~b}$. The distances between the tree and blade weeder may be estimated by using the following formula: $\mathrm{DF}=\delta^{*} \cos 30^{\circ}$

Where DF is the distance between the trunk tree and bade weeder. A helical spring is made from a steel wire of $2.4 \mathrm{~mm}$ diameter and outside diameter $24 \mathrm{~mm}$. The number of coils is 92 coil and the modules of rigidity assumed as $84 \times 10^{3} \mathrm{~N} / \mathrm{mm}^{2}$. The load, which the spring can carry, it measured by using the balance. The deflection of the spring was calculated by using the following equation: $\delta=8 \mathrm{WD}^{3} \mathrm{n} /\left(\mathrm{Gd}^{4}\right)$ (Khurmi and Gopta, 2004) Whereas: $\delta$ is the distance between the blade weeder and trunk trees, $D$ is the outside of spring, $n$ is the number of coils and $G$ is the modules of rigidity of steel. The different load due to the tracking of the rolling wheel on the trunk trees was measured and listed in table 1 at different rolling wheel level. The rolling wheel level on the trunk tree 
could be adjusting by change the angle between rolling wheel bar and their position on the main beam of swing mechanical arm. It noticed that the maximum adjusting distance of blades near the trunk trees was 85.6 $\mathrm{mm}$ and minimum distance $46.8 \mathrm{~mm}$. The above laboratory tests were made to obtain the optimum nearly distance of blades to the trunk trees. It adjusted at first level $54 \mathrm{~mm}$ under experimental field conditions. The experimental field carried out under orange (Citrus sinensis L. Osbeck) field conditions in farm research of faculty of agriculture, Kafrelsheikh University, Egypt. A prototype electric Weeder evaluated under three forward speed $3.2 \mathrm{~km} \mathrm{~h}^{-1}, 4.1 \mathrm{~km} \mathrm{~h}^{-1}$ and $5.7 \mathrm{~km} \mathrm{~h}^{-1}$ at three rotational speed $1600 \mathrm{rpm}, 2200 \mathrm{rpm}$ and $2600 \mathrm{rpm}$ for weeder. Full implement testing was conducted to observe how the implement could may able to distinguish orchards trees trunk and circumvent them. Light implement frame adjustment an electric weeder under orange trees citrus to remove and cutting the weeds. The base frame serves as tool carrier for swing mechanical arm. This structure allows the independent lifting of one side and height adjustments in depth wheel and tractor hydraulic system as shown in figures 3 and 4 . When the tractor operated the swing, mechanical arm of the electric weeder than the rolling wheel rotate on the trunk of trees and pushed the mechanical arm to adjusting the blades near the trees for $54 \mathrm{~mm}$ to mow the weeds. The population densities were measured in the intra-row region by using the wood frame. All trees within this frame were counted. The weeder efficiency was calculated by using the following formula:

$W_{\text {eff }}=\frac{W_{\text {affer }}}{W_{\text {before }}} \times 100$

$\mathrm{W}_{\text {eff }}=$ weeder efficiency, $\%, \mathrm{~W}_{\text {befor }}$ and $\mathrm{W}_{\mathrm{after}}$ are the number of weeds before and after weeder operating in orange field.

Table 1: The distance between the blade weeder and trunk trees at different rolling wheel level

\begin{tabular}{|l|c|c|c|}
\hline $\begin{array}{c}\text { Rolling } \\
\text { wheel level }\end{array}$ & $\begin{array}{c}\text { measured load, } \\
\mathrm{N}\end{array}$ & $\begin{array}{c}\text { Distance near the blade } \\
\text { to trunk trees, } \\
\mathrm{mm}\end{array}$ & $\begin{array}{c}\text { Spring } \\
\text { deflection, mm }\end{array}$ \\
\hline Level1 & 20.4 & 46.82 & 54.06 \\
\hline Level2 & 24.6 & 56.45 & 65.19 \\
\hline Level3 & 37.3 & 85.60 & 98.84 \\
\hline
\end{tabular}




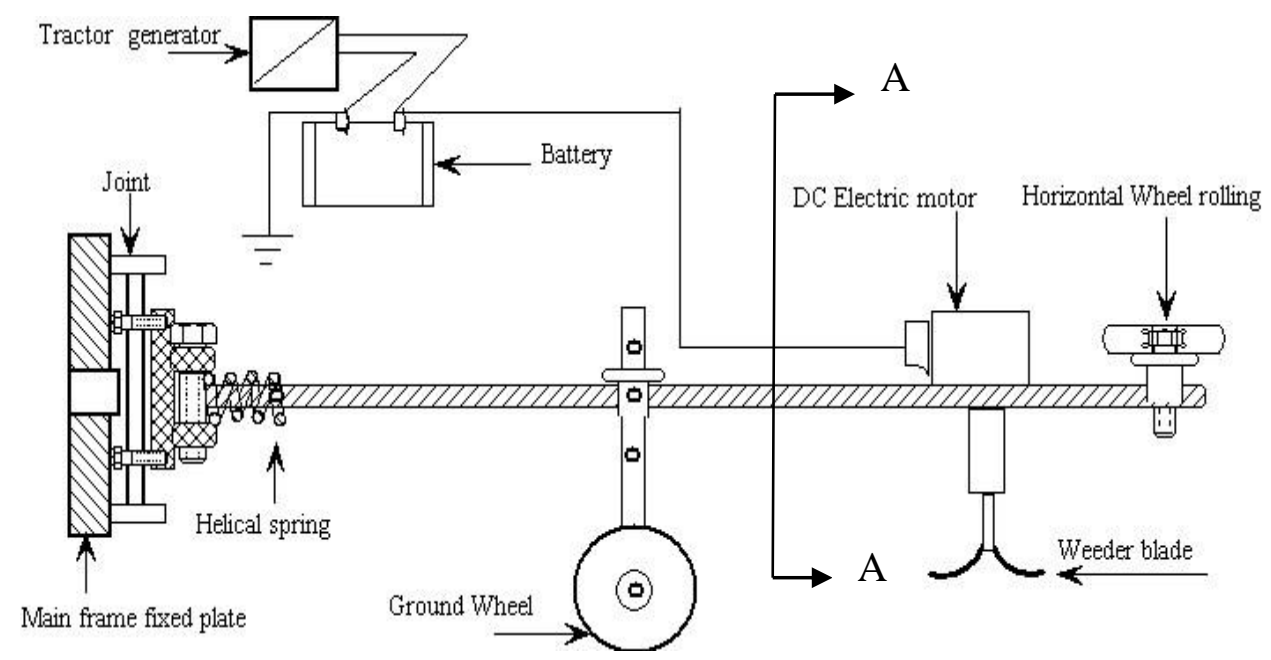

Fig.1: The sketch diagram of a manufactured swing mechanical arm with electric weeder.

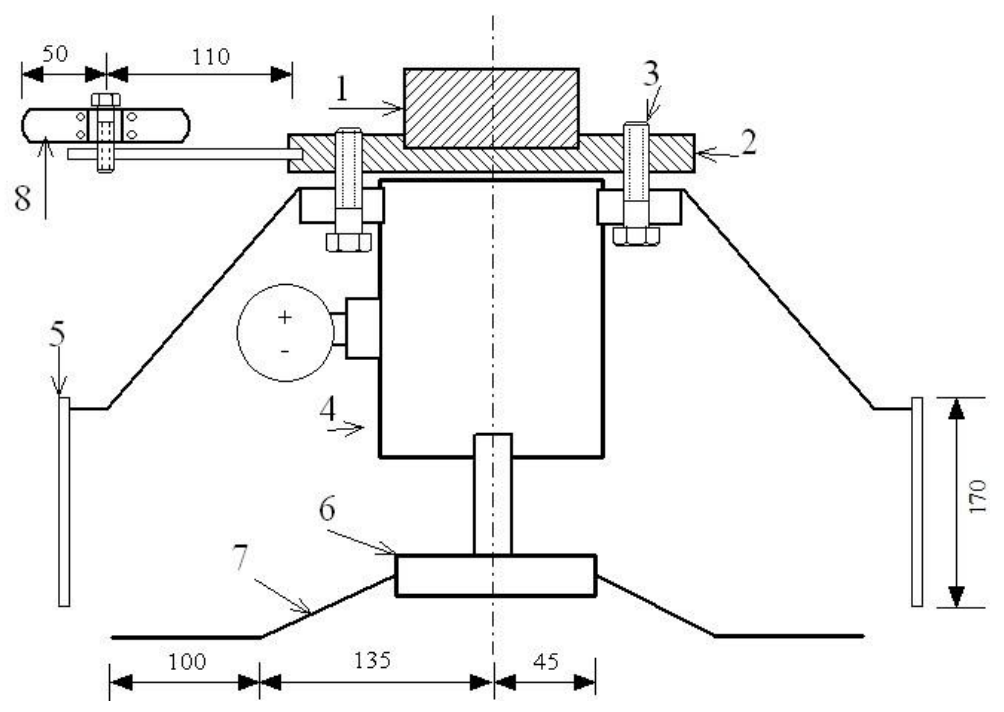

1-Swing mechanical arm

4- DC motor

6-Teflon disk 7-Blades
2-Fixed plate 3-Bolts

5- Protecting plate (P. glass)

8-Wheel marker

Fig. 2: The sketch diagram for the cross-sectional (A-A) in developed electric weeder. 


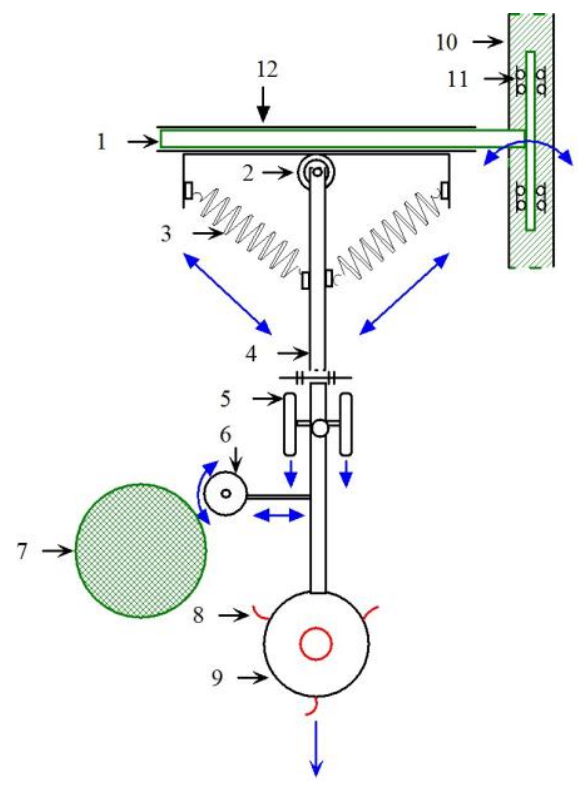

(a)

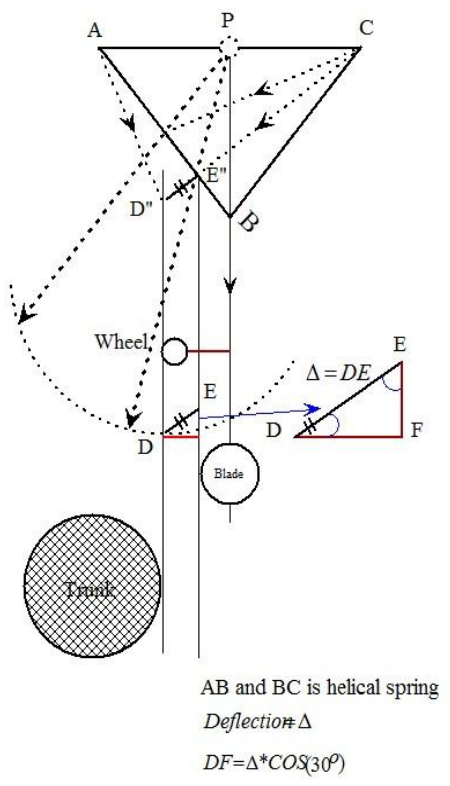

(b)
1-Steel bar $60 \mathrm{~cm} \quad$ 2-fixed joint with pins

4- Beam $2.54 \times 2.54 \mathrm{~cm} \quad 5$ - Two ground wheels

7- Tree trunk

10- Main frame
3- Two helical springs

6- Rolling wheel

9- Electric weeder

Fig.3: The sketch diagram of controlled of distance between swing mechanical arm and trunk trees during operation (a) and analysis diagram of the distance .between the blades and trunk of trees.
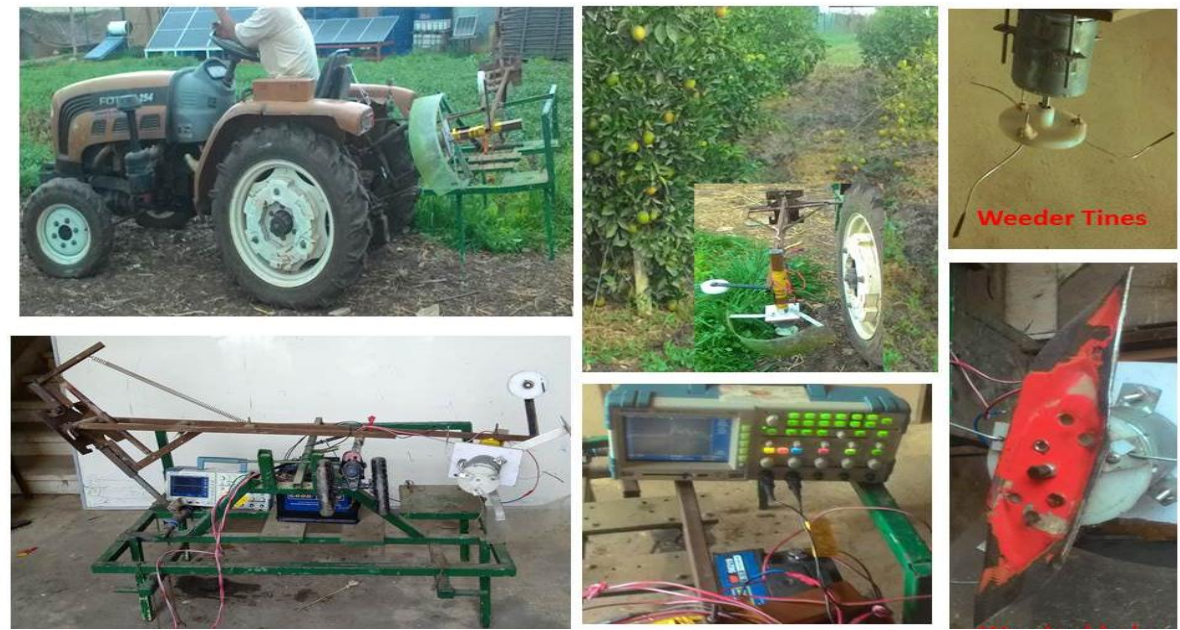

Fig.4: The manufactured swing mechanical arm with electric weeder in laboratory and field conditions. 


\section{RESULTS AND DISCUSSION}

The result for laboratory test indicated that the electric power for the developed weeder at different rotational speed 1600, 2200, and $2600 \mathrm{rpm}$ increased due to increase the rotational speed. The operating of weeder with blade required more electric power compared to the operating of the weeder with three tines. State of Charge (SOC) of the battery was found at the range between the values of 0.749 to 0.847 . This result indicated that, the dry battery will be saved during the operating of the electric weeder as shown in figure 5. On the other hand, the cutout circuit adjusted to recharge before the SOC value reached to 0.8 . Table 2 shows the average of fuel consumption and weeder electric power for the developed weeder under citrus orange tree field conditions. The increasing of rotational speed tends to increase the electric power requirement. In addition, the blades required more power compared to tines. The maximum electric power was $73.2 \mathrm{~W}$ for blades compared to $57.1 \mathrm{~W}$ for tines at forward speed $5.7 \mathrm{kmh}^{-1}$ and rotational speed 2600 rpm. It has noticed that there was non-significant effect of rotational speed and type of blades on fuel consumption at constant forward speed. On the other hand, manufacturing swing electric Weeder may be operating by the tractor without more fuel consumed. The electric power produced from the tractor generator was able to operate the developed weeder. The increasing of forward speed tends to increase the fuel consumption at second gear in tractor. The maximum fuel consumption was $8.64 \mathrm{~L} \mathrm{~h}^{-1}$ for blades and tines at rotational speed of weeder 2600 rpm. The minimum average value of fuel consumption was $7.2 \mathrm{Lh}^{-1}$ for blade and tines at rotational speed of weeder $1600 \mathrm{rpm}$. Table 3 illustrates the number of weeds $/ \mathrm{m}^{2}$ in row orchards tree before and after treatment with a manufactured swing electric weeder. The increasing of rotational speed tends to decrease the number of weeds $/ \mathrm{m}^{2}$. In addition, the blade gave low number of weeds $/ \mathrm{m}^{2}$ compared to the tines under all treatment conditions. Figure 6 indicate the increasing of forward speed tends to decrease the weed efficiency. The maximum weed efficiency was $98.3 \%$ at forward speed $3.2 \mathrm{kmh}^{-1}$ and rotational speed $2200 \mathrm{rpm}$ for blades and tines. The forward speed $5.7 \mathrm{kmh}^{-1}$ gave the lower values of the weed efficiency. On the other hand, the blades with $180^{\circ}$ degree set produced 
the high weed efficiency compared to three tines with $120^{\circ}$ degree setting. The minimum value of weed efficiency for blades was $89.5 \%$ compared to $85.2 \%$ for Tines at forward speed $5.7 \mathrm{kmh}^{-1}$ and rotational speed 2600 rpm as shown in figures 6 and 7. As well as the increasing of weeder rotational speed tends to increase the weed efficiency. The weed efficiency at $5.7 \mathrm{kmh}^{-1}$ forward speed and blades with $180^{0}$ degree were $89.5 \%, 94.7 \%$ and $95.8 \%$ for rotational speed $1600 \mathrm{rpm}, 2200 \mathrm{rpm}$ and $2600 \mathrm{rpm}$ respectively. The Tines gave the above same trend for the operating electric weeder.

Table 2: Average of fuel consumption $\mathrm{L} \mathrm{h}^{-1}$, weeder electric power for a development weeder under citrus orange tree field conditions.

\begin{tabular}{cccccc}
\hline \multicolumn{2}{c}{ treatment } & \multicolumn{2}{c}{ Fuel consumption, L } & \multicolumn{2}{c}{ Electric power, W } \\
$\begin{array}{c}\text { Forward } \\
\text { speed, } \mathrm{kmh}^{-1}\end{array}$ & $\begin{array}{c}\text { Rotational } \\
\text { sp., rpm }\end{array}$ & Tines & Blades & Tines & Blades \\
\hline 3.2 & 1600 & 7.20 & 7.19 & 43.5 & 66.1 \\
& 2200 & 7.18 & 7.19 & 48.2 & 67.3 \\
& 2600 & 7.20 & 7.20 & 51.3 & 69.2 \\
4.1 & 1600 & 7.95 & 7.96 & 46.5 & 68.1 \\
& 2200 & 7.95 & 7.96 & 48.2 & 69.3 \\
5.7 & 2600 & 7.96 & 7.96 & 51.3 & 69.8 \\
& 1600 & 8.64 & 8.66 & 48.5 & 66.1 \\
& 2200 & 8.64 & 8.64 & 48.9 & 69.9 \\
& 2600 & 8.64 & 8.64 & 57.1 & 73.2 \\
\hline
\end{tabular}

\section{SUMMARY AND CONCLUSIONS}

Results illustrated that rotational speed and forward speed affected the weeder efficiency. As well as, the increasing of forward speed, reduce the weed control under orange field conditions. The blades weeder was more effective in controlling weeds than the Tines. In addition, the power requirement of the swing mechanical arm with electric weeder could be operating with the tractor without increasing of the fuel consumption. The operating of weeder with blade required more electric power compared to operate of the weeder with three tines. The type of blades was non effect on fuel consumption at constant forward speed. The increasing of rotational speed was non-effect on the fuel consumption. 
Table 3: Display the number of weeds $/ \mathrm{m}^{2}$ before and after operating the manufactured development weeder under citrus orange tree field conditions.

\begin{tabular}{|c|c|c|c|c|c|}
\hline \multicolumn{2}{|c|}{ Treatments } & \multicolumn{2}{|c|}{$\begin{array}{c}\text { Number of weeds } \\
\text { before trail }\end{array}$} & \multicolumn{2}{|c|}{$\begin{array}{l}\text { Number of weeds } \\
\text { after trail }\end{array}$} \\
\hline $\begin{array}{c}\text { Forward } \\
\text { speed, } \mathrm{kmh}^{-1}\end{array}$ & $\begin{array}{l}\text { Rotational } \\
\text { sp., rpm }\end{array}$ & Tines & Blades & Tines & Blades \\
\hline \multirow[t]{3}{*}{3.2} & 1600 & 80 & 86 & 7 & 2 \\
\hline & 2200 & 72 & 55 & 5 & 1 \\
\hline & 2600 & 97 & 39 & 7 & 2 \\
\hline \multirow[t]{3}{*}{4.1} & 1600 & 91 & 63 & 10 & 6 \\
\hline & 2200 & 83 & 47 & 9 & 4 \\
\hline & 2600 & 68 & 56 & 6 & 2 \\
\hline \multirow[t]{3}{*}{5.7} & 1600 & 54 & 38 & 8 & 6 \\
\hline & 2200 & 62 & 48 & 8 & 3 \\
\hline & 2600 & 82 & 57 & 9 & 3 \\
\hline
\end{tabular}

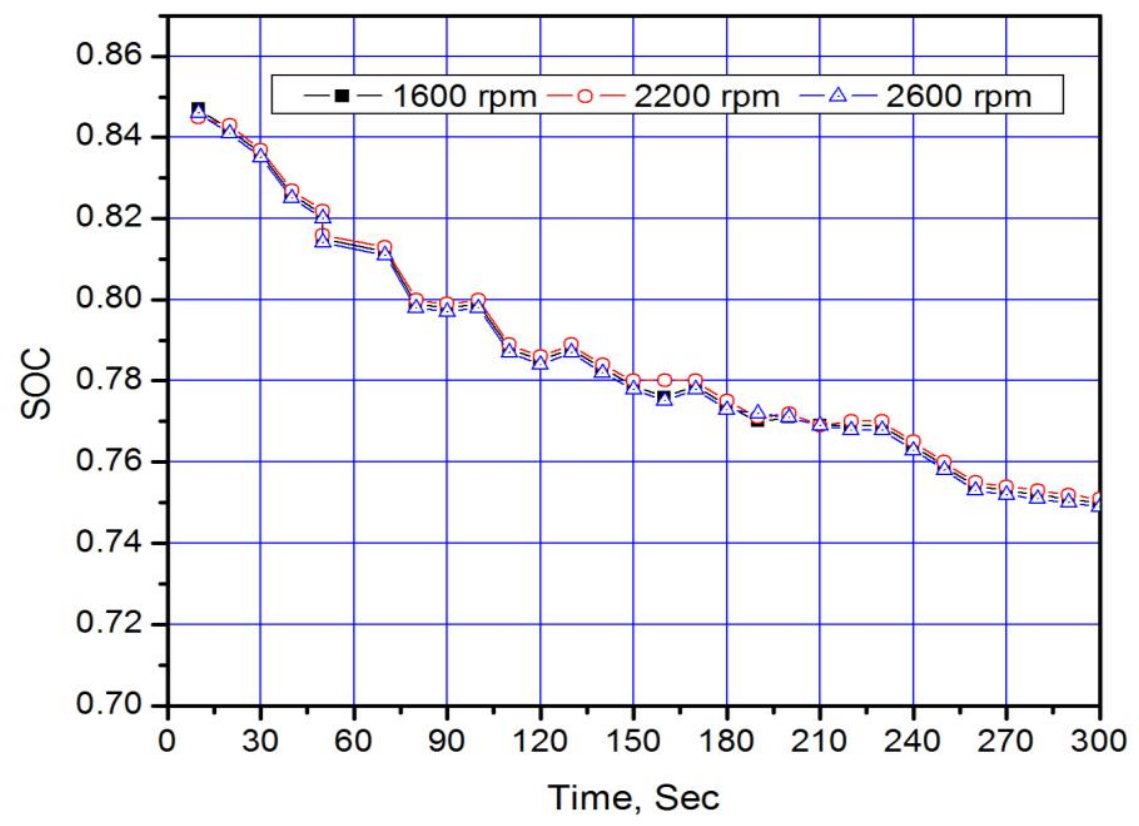

Figure 5: The state of charge (SOC) for the manufactured swing mechanical weeder arm at different rotational speed 


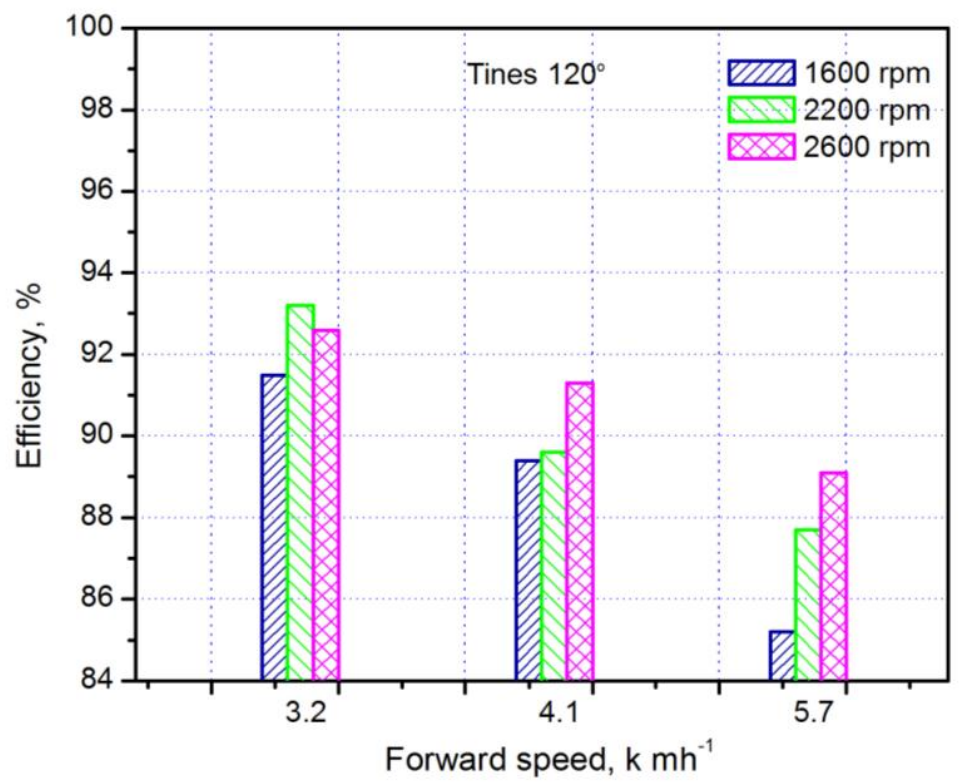

Figure 6: The weed efficiency for the manufactured weeder at different forward speed and rotational speed in orange trees field for tines.

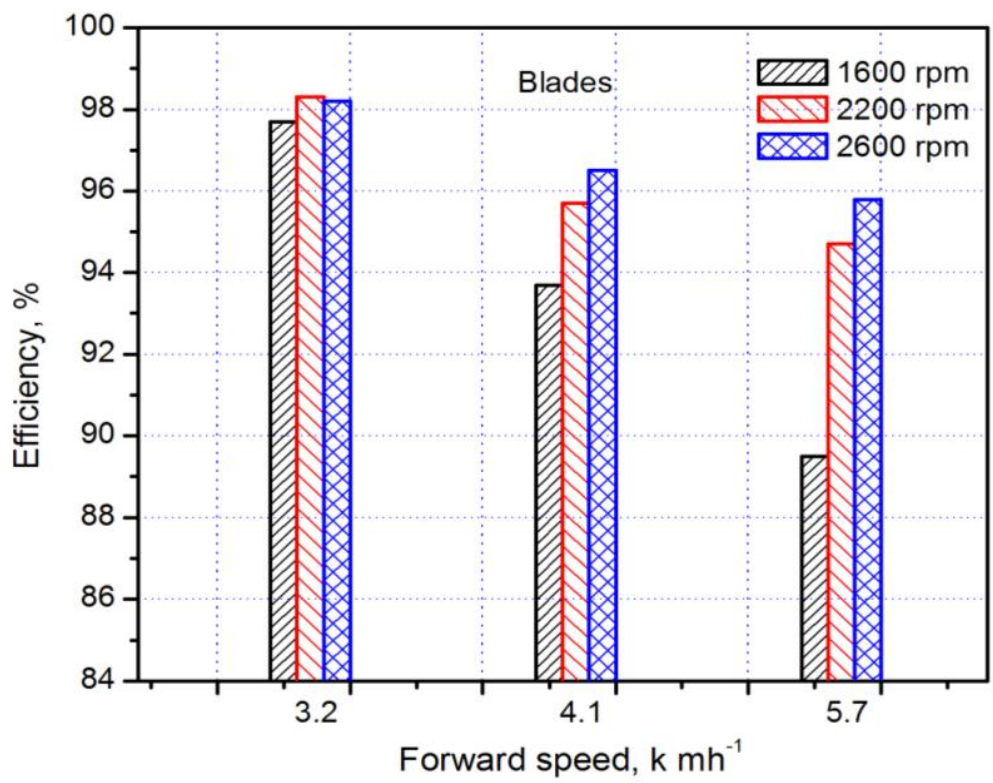

Figure 7: The weed efficiency for the manufactured weeder at different forward speed and rotational speed in orange trees field for blades type. 


\section{REFERENCES}

Ascard. J.and F. Fogelberg (2008) Mechanical in-row weed control in transplanted and direct-sown bulb onions. Biol. Agric. Hortic. 25:235-51.

Bajwa. A.A., G. Mahajan, and B.S. Chauhan 2015. Nonconventional weed management strategies for modern agriculture. Weed Sci. 63:723-47.

Barberi P. (2002) Weed management in organic agriculture. Weed Res.42(3): 177-193.

Bleeker P.O., R.Y. van der Weide, and D. Kurstjens (2002) Experiences and experiments with new in-row weeders. pp 97-100 in Proc. 5th EWRS Workshop on Physical and Cultural Weed Control, Pisa, Italy.

Cloutier, D.C., M. LeBlanc and E. Johnson. (2007a) Non-inversion production techniques in North America. In D.C. Cloutier, B. Melander, B. Gerowitt, eds. 7th EWRS Workshop on Physical and Cultural Weed Control. EWRS, Salem, Germany, p. 3-14.

Cloutier, D.C., R.Y. van der Weide, A. Peruzzi and M. LeBlanc. (2007b) Mechanical weed management. In M.K. Upadhyaya, R.E. Blackshaw, eds. Non-chemical Weed Management: Principles, Concepts and Technology. CABI, Oxon, UK, p. 111-134.

Fontanelli, M., C. Frasconi, L. Martelloni, M. Pirchio, M. Raffaelli, and A. Peruzzi (2015a). Innovative strategies and machines for physical weed control in organic and integrated vegetable crops. Chem. Engine. Trans. 44:211-6.

Ge, Z.Y., W.W. Wu, Y.J. Yu, and R.Q. Zhang (2013) Design of swing mechanical arm for laser weeding robot. Appl. Mechan. Mater. 347350:834-8.

Griepentrog HW, Norremark M, Nielsen J, Soriano Ibarra J (2007) Autonomous inter-row hoeing using GPS based side-shift control. Agricultural Engineering International - The CIGR E.journal IX(Manuscript ATOE 07 005) 
Khurmi R.S and J.K. Gupta (2005) A textbook of machine design. EURASIA PUBLISHING HOUSE (PVT.) LTD.RAM NAGAR, NEW DELHI-110 055.

Martelloni L., M. Fontanelli, C. Frasconi, M. Raffaelli, and A. Peruzzi 2016a. Cross-flaming application for intra-row weed control in maize. Appl. Eng. Agr. 32

Martelloni, L., C. Frasconi, M. Fontanelli, M. Raffaelli, and A. Peruzzi (2016b) Mechanical weed control on small-size dry bean and its response to cross-flaming. Span. J. Agric. Res. 14:e0203.

Marx, C., S. Barcikowski, M. Hustedt, H. Haferkamp, and T. Rath 2012a. Design and application of a weed damage model for laser-based weed control. Biosyst. Eng. 113:148-57.

Marx C., J.C. Pastrana Pérez, M. Hustedt, S. Barcikowski, H. Haferkamp, and T. Rath 2012b. Investigations on the absorption and the application of laser radiation for weed control. Landtechnik. 67:95101.

Mathiassen, S.K., T. Bak, S. Christensen, and P. Kudsk 2006. The effect of laser treatments as a weed control method. Biosyst. Eng. 95:497505.

Melander, B. (1998) Interactions between soil cultivation in darkness, flaming, and brush weeding when used for in-row weed control in vegetables. Biol. Hortic. Agric. 16:1-4.

Ministry of Agriculture, Egypt (2015) Annual report of general administration of plant quartile (GRPQ).

Pérez-Ruiz, M., P. Gonzalez-de-Santos, A. Ribeiro, C. FernandezQuintanilla, A. Peruzzi, M. Vieri, S. Tomic, and J. Aguëra (2015) Highlights and preliminary results for autonomous crop protection. Comput. Electron. Agr. 110:150-61.

Raffaelli, M., P. Bàrberi, A. Peruzzi, and M. Ginanni (2005) Mechanical weed control in maize: evaluation of weed harrowing and hoeing systems. Agr. Med. 135:33-43. 
Raffaelli M., L. Martelloni, C. Frasconi, M. Fontanelli, S. Carlesi, A. Peruzzi (2016) A prototype band-steaming machine: design and field application. Biosys.Eng.144:61-71.

Sehsah, E.M (2018) "Manufacturing a prototype swing mechanical arm Weeder for orchard trees" Poster in $18^{\text {th }}$ International Conference on Organic Fruit Growing Universität Hohenheim (Germany), February 17 to $21,2018$.

Strunz K, and H. Louie (2009) Cache energy control for storage: power system integration and education based on analogies derived from computer engineering. IEEE Trans Power Syst 24 (1):12-19.

Van der Weide R.Y., P.O. Bleeker, V.T.J.M. Achten, L.A.P Lotz, F. Fogelberg, B. Melander (2008) Innovation in mechanical weed control in crop rows. Weed Res. 48:215-24.

Young K., C. Wang, L. Y. Wang, and K. Strunz (2013) Electric Vehicle Battery Technologies. http://www.springer.com/978-1-4614-0133-9

\section{الملخص العربي \\ نموذج أولى لذراع ميكانيكى متأرجح لمكافحة الحشائش لأشجار الفاكهة د/ السيد محمود البيلى صحصاح*}

تهدف الدر اسة الى تصنيع ذر اع ميكانيكى متأرجح مزود بمحشة دور انية تعمل بمحرك كهر كهربائى

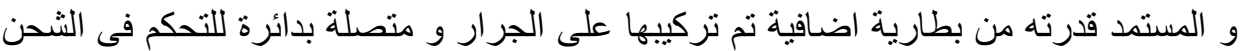

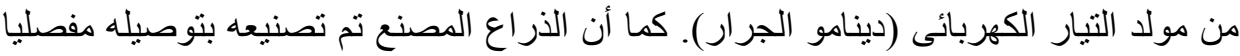

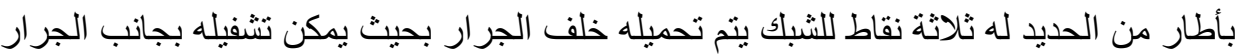

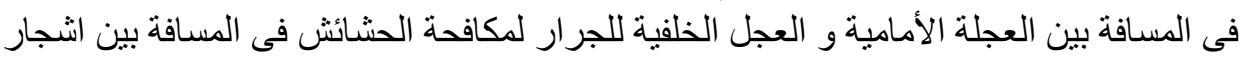

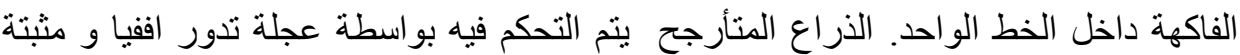

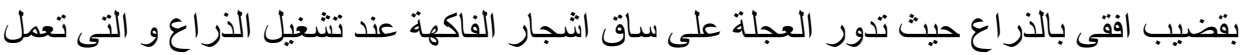

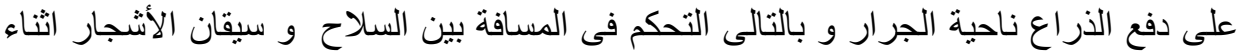

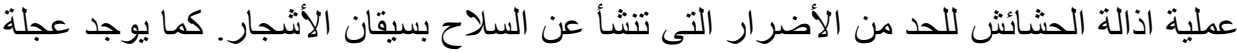

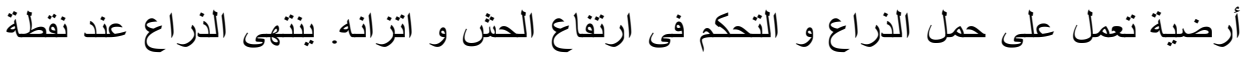

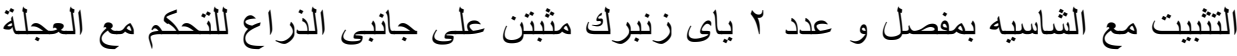

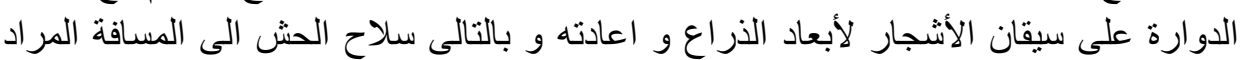

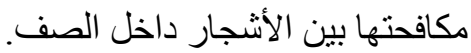

*أستاذ مساعد بقسم الهندسة الزراعية ـ كلية الزراعة - جامعة كفرالثيخ - مصر 
أستعمل جهاز Tektronix Oscilloscope Model TPS 2024 لقياس القدرة الكهربية معملياو اثناء التشغيل و جهاز Digital Tachometer Laser HP-2234C لقياس السرعة

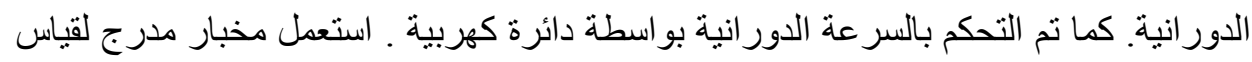

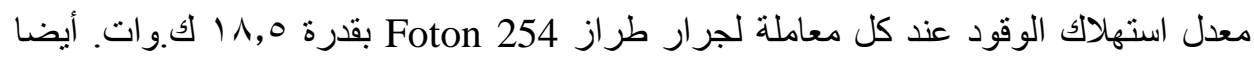

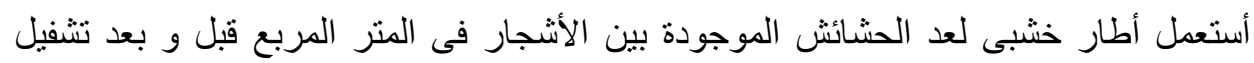

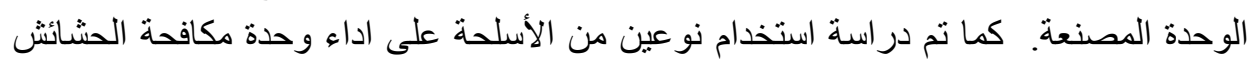

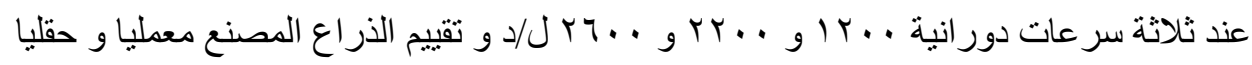

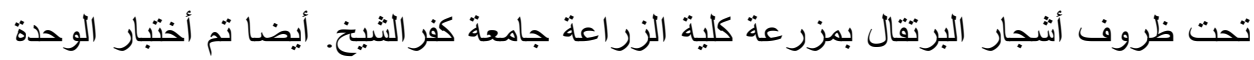

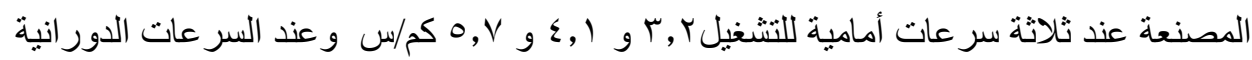

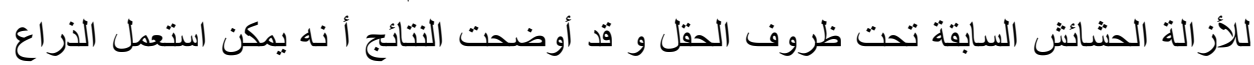

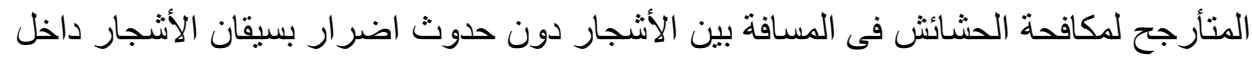

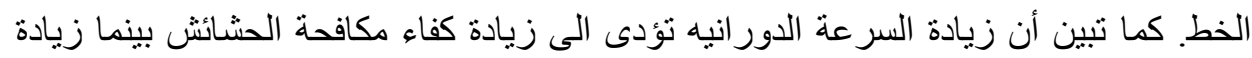

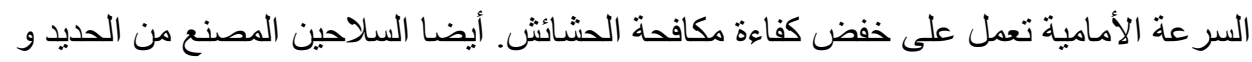

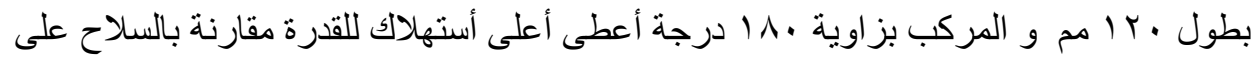

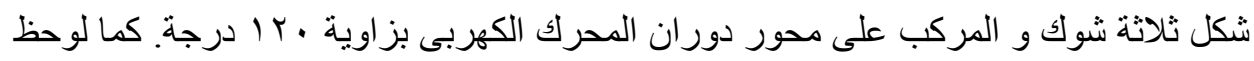

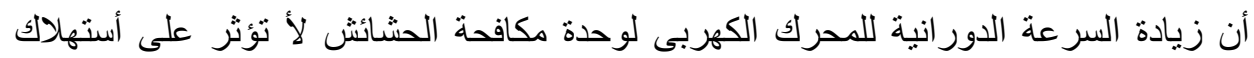

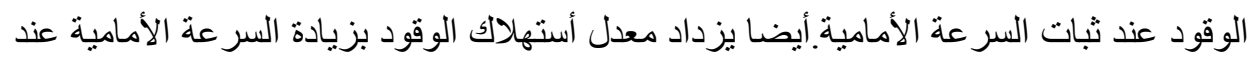

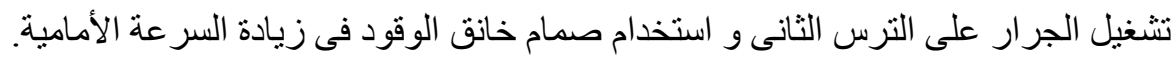

